\title{
A study on the organization and management systems of Turkish shipping companies
}

\author{
Ergun Demirel ${ }^{1}$
}

\begin{abstract}
The Turkish maritime posture is changing rapidly. Turkish shipowners now have over 30.3 millions DWT fleet and modern and big size ships replacing old vessels. The quantity and quality of the ports and terminals are significantly increasing. The shipping companies are reorganizing to adapt themselves for new operational and economic requirements. Better organizations and management systems are required to support this modernized fleet and improving shore facilities.

The shipping companies are the leading element of the shipping sector. They play a crucial role in understanding existing and future requirements for national maritime industry and they develop plans, programmes and policies to survive in today's challenging world.

The shipping sector introduces a volatile character and it is not transparent. Therefore, it is not so easy to gather information on all the aspects of the shipping companies such as financial status, future plans and strategies. On the other hand, it is relatively easier to collect information on organization and management systems of the companies, which provide significant information on their capabilities and modus operandi.

In this study it is intended to make a SWOT analysis of these companies based on their organization and management systems, using the expertise and different views of the professionals. In light of the results of the analysis, some findings which may lead to future studies are also discussed.
\end{abstract}

Keywords: Shipping Companies, Company Organization, Company Management, Turkish Shipping, Management Systems, SWOT Analysis

\section{Introduction}

At the beginning of the year 2012 the available figure of the total number of vessels over $1000 \mathrm{GT}$ that Turkish Commercial fleet had, was 627. That corresponds to a capacity of transportation reaching to 9.488.719 DWT. Considering 20.838 million DWT ships operating under other flags; the total amount of the ships owned by Turkish shipowners reaches 30.337 million DWT. This

\footnotetext{
1 Asst. Prof. Dr., Piri Reis University, Maritime Faculty, Maritime Transportation and Management Engineering, Turkey, edemirel@pirireis.edu.tr
} 
Demirel, E. (2015). A study on the organization and management systems of Turkish shipping companies. International Journal of Human Sciences, 12(2), 51-74. doi: 10.14687/ijhs.v12i2.3165

value is actually, ranking Turkey $13^{\text {th }}$, among the countries which are known to be the world's largest commercial fleet (IMEAK, 2013).

General overview of the Turkish Maritime Sector is changing rapidly. Currently, by adding the number of vessels registered in other nations, the total figure that the Turkish shipowners has, is going to be around 30 million DWT. Meantime the old vessels in our fleet are replaced by modern and large-capacity vessels. So that the ships of Turkish Maritime fleet by doing so, have also been quite rejuvenated / renovated. Parallel to that within the last ten year period, the number of harbours / ports, terminals of the sector and their quality has been significantly improved. Three quarters of the commercial fleet have been built in Turkey. The majority of the Turkish fleet consists of dry cargo and bulk carriers. Dry cargo ships, oil and rejuvenated chemical tankers are traditionally being built in Turkey; just a small amount is imported from abroad. In contrast, only twenty percent of bulk cargo vessels are being constructed in Turkey whereas a vast majority of the RO-RO ships are being built abroad. Shipbuilding activities of Turkish Shipyards continue to decline as of 2008, as the result of the experienced economic crisis all around the world. With the help of repair and maintenance of existing ships at our shipyards has supported the activities of the shipbuilding sector for the past two years and hence it has maintained its vitality.

Shipping companies and organizations are reorganizing themselves to meet the new requirements of the operational and economic structures in such a manner that it has to be compatible with the contemporary needs as well. As the result of having both this modernized fleet and shore facilities such as ports, shipyards, companies, logistics units, have consequently caused to emerge of having highly qualified staff.

Within the last 10 years, the IMO (International Maritime Organization) codes and regulations have passed through pretty big changes and that is expected to continue even with a higher momentum in the coming years as well. Hence in order to be in competence with this strong competition that has been emerged in our country, not only the ships / equipment and facilities but the available qualified manpower, organizations and management systems of the related companies also have to be compatible to meet the requirements.

The maritime industry is now an important element of the Turkish economy. In order to survive in today's competitive environment in this sector, the new requirements have to be met, especially the demand of having skilled/qualified manpower and reorganizing themselves to be successful in the world challenging maritime industry. 
Demirel, E. (2015). A study on the organization and management systems of Turkish shipping companies. International Journal of Human Sciences, 12(2), 51-74. doi: $10.14687 /$ ijhs.v12i2.3165

The shipping companies are the leading actors which drives the shipping sector. And it is clear that organization and management are key factors which directly affect the success in the business. It is intended to start a research on the organization and management systems of these companies.

The shipping business is not wholly transparent (Drewry, 2006) and it is not so easy to gather information on the shipping companies. Some major companies have been selected as target groups and names are kept under wrap to protect privacy.

\section{Research method}

The aim of this study is to conduct a research on the organizations and management systems of the Turkish shipping companies and to define problem areas which may introduce some solutions in a limited content.

The research is conducted in three phases. In the first phase it is intended to gather detailed information on the organization and management systems of the companies and to prepare the gathered information for a SWOT study. This phase also covers conceptual approaches of the management. The problems which are mostly encountered are assumed to be of priority items and accordingly studied.

The second phase covers a SWOT analysis carried out by an expert group of five persons. The strengths and weaknesses are also evaluated with a PRIMO (Priority and Importance) test to be taken into consideration at the opportunities and threats analysis stage. Based on the weakness and strengths, the opportunities and the threats are defined and PESTEL (Political, Economic, Social, Technologic, Environmental and Legal) test applied before introduction for an overall evaluation.

In the final phase the threats and opportunities evaluated taking into account impacts of the company operations in particular the areas may create strategic, financial and operational risks. The results of impact analysis are categorised, grouped and associated if possible and the final study has been made to formulate possible/probable solutions to overcome the problems which directly affect the survivability and success of the shipping companies. 
Demirel, E. (2015). A study on the organization and management systems of Turkish shipping companies. International Journal of Human Sciences, 12(2), 51-74. doi: 10.14687/ijhs.v12i2.3165

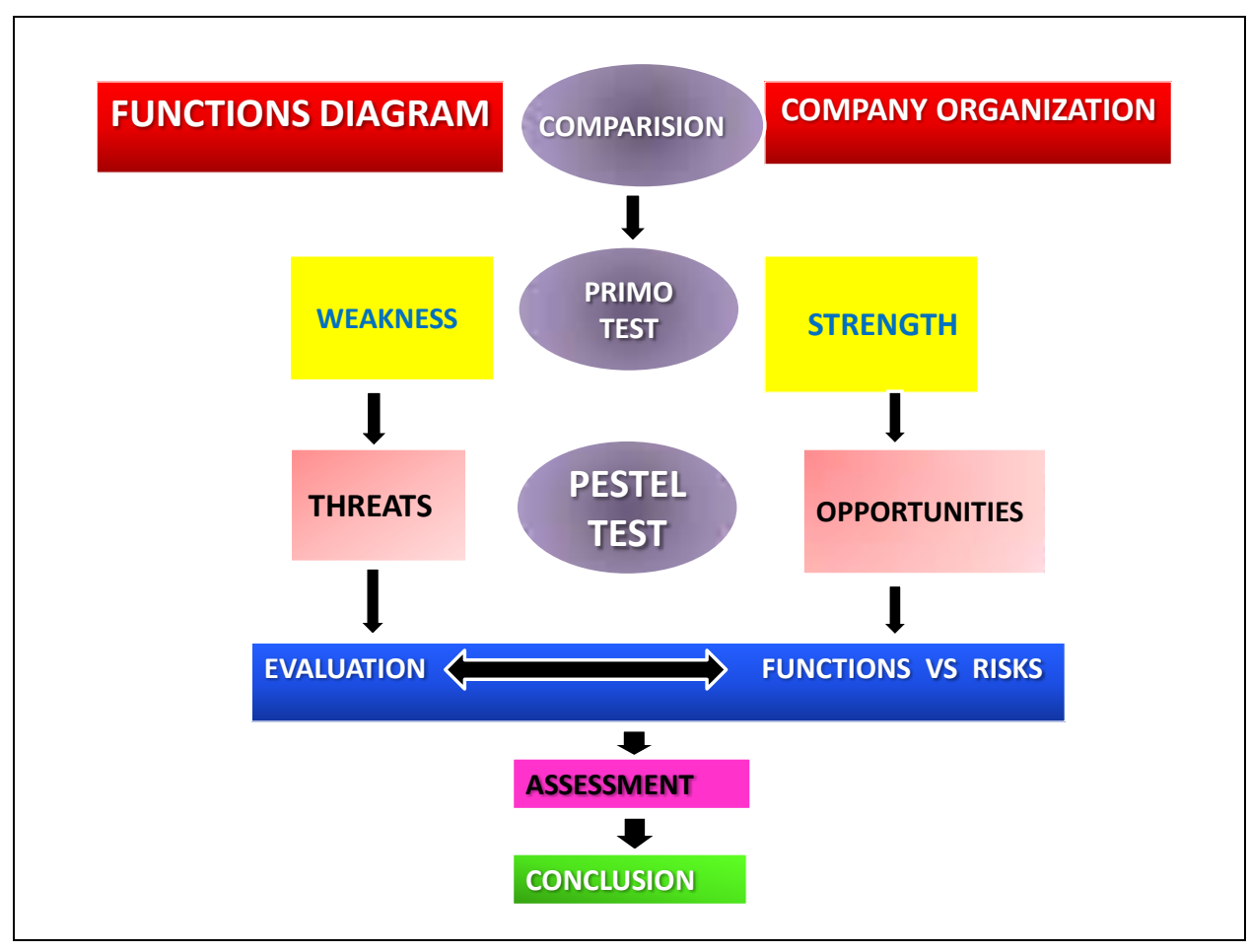

Figure 1: The research method applied

\section{A brief history of Turkish shipping}

The European countries gained many special rights and capitulations after the proclamation of Tanzimat Edict (Reorganization of the State) in 1839. Having this opportunity, Western countries seized control of approximately the whole shipping activities in the Ottoman Empire. They opened many shipping, ship-brokering and ship-chandler companies at major ports. These companies generally deployed Christian and Jewish minorities due to linguistic and cultural similarities. The minorities held critical positions and even they established their own shipping companies (Cogito, 2006).

By the end of the $19^{\text {th }}$ century; the Ottoman Empire was in a mire of debt and the Ottoman treasury came under control of European countries and they gained additional capitulations. The Ottoman ports passed the control of foreigner in this period (Ortayli, 2006). The number of the Ottoman flag ships was not sufficient (130,000 gross ton). As a result of the enhanced capitulations and cabotage rights related to shipping in 1861, the Europeans dominated the sector throughout the country (Sirin, 2000). This situation caused major problems in the transportation systems of the country and the Empire established a state-owned shipping company (Seyr-i Sefain Idaresi) to govern both merchant shipping as well as in support of naval transportation in 

Journal of Human Sciences, 12(2), 51-74. doi: $10.14687 /$ ijhs.v12i2.3165

1910. This organization continued to exist in the Turkish Republic period up until 1933 (Camci et al, 1994).

The shipping system in Turkey remained under control of the allied countries after World War One. The newly established Turkish Republic could not establish his own shipping system between 1923-1925 periods due to lack of sufficient infrastructure and manpower to handle the system. The international shipping was still being controlled by foreigners. The local shipping was conducted by Turkish companies organized under then Mavnacilar Birlikleri (Associations of Barge Operators). The Law of the Ports was passed in 1928 to solve this problem and state supported shipping companies and port administrations were launched. The national Turkish Commerce Association (Milli Turk Ticaret Birligi) started a campaign for the nationalization of shipping (Avcioglu, 1969)

The main problem was the provision of qualified personnel for the shipping industry. The only source for seafaring officers and shore personnel was the Naval Academy. There was no institute to support the merchant fleet crew and the Merchant Fleet School which had been opened in 1881 and shut down in 1888 (Sirin, 2000). The existing shipping companies were being operated by foreigners or minorities who almost became estranged (Cogito, 2006).

Turkish shipping could not be improved during the $2^{\text {nd }}$ World War. Turkey could not get benefit to enhance his fleet when the United States disposed of Liberty class cargo ships, only 5 ships were bought.

After 1950 the liberal economy era started and many shipowners started to become involved in shipping. Also a state-owned shipping company named DB Nakliyat (Turkish Cargo Lines) to serve for both domestic and international shipping is established. The private sector reached 553,304 DWT as the stated owned ships were 287.518 DWT in the year 1967.

In 1980, the shipping industry was the beginning of the dark days and second-hand ship sales started with very low prices. The Turkish Chamber of Shipping was founded in 1981 and it became an important tool to organize private shipping sector. The newly established Undersecretariats of Maritime Affairs directly reporting to Prime Ministry assumed maritime administration functions. The Following year the government published a law concerning "Improvement of the Merchant Fleet and Incitement of Shipbuilding Industry" which has 
provided ship finance for the shipowners up to 90 percent and guarantee for the freight (Turkish Government, 1982). Many new shipping companies have been established. This incitement allowed the shipowners to buy mainly second-hand ships and the tonnage of the fleet suddenly increased to 5.123.888 DW'T in 1989.

The beginning of the third millennium was a golden era for Turkish shipping. The high freight rates encouraged the shipowner to enhance and renew their fleet. Old ships have been decommissioned, scrapped or sold and subsequently new, modern and bigger ships have entered service. The same efforts have been spent to improve shipyards and ports. Most importantly private sector and government agreed to apply higher standards as required in the new world order. Many maritime education institutes have been opened to support this modern fleet. The economic crisis in the 2008 has created a negative impact on the shipping industry. The sector has been badly influenced from the crisis but achieved to survive.

The country's Eastern Black Sea coast has very limited economic opportunities. This situation has led to people turning to shipping and fisheries. Still in the country, the vast majority of shipowners and sailors are originally from this region. This situation can easily be organized to ship owners and township-relations have provided mutual support and interdependence. They have also got involved in shipyard and port operation business. The shipping companies of this group introduce a small family type of business and they hand over the positions from one generation to another. Albeit the new Trade Law is brought obligation to use professionals in the management boards of on the boards of such companies, this is solved by family solidarity.

Although there are many shipowners from the other regions, ten to twenty families from the Black Sea region lead the private maritime sector. The Turkish shipowners generally operate their ships under convenient flags or Turkish second registration. The economic data for ship owners therefore is not reflected in the economic figures of the country and their real economic value is not known.

Turkish merchant fleet today is mainly composed of bulk carriers, but meanwhile one can observe a gradual increase in the number of tankers and container ships. At the same time the Turkish shipping companies modify themselves parallel to this change. ARKAS, YASA, MARDAS, BESIKTAS, TURKON, INCE and GEDEN Shipping are some outstanding companies who have started to this path and may other companies try to follow the same path. 

Journal of Human Sciences, 12(2), 51-74. doi: $10.14687 /$ ijhs.v12i2.3165

\section{Pre-SWOT studies}

The organization and management is vital for any type of institutions. The following paragraphs explain clearly the importance of the organization and management systems for the survival and success of a corporation.

The philosophy and mission of an organization is the core of its existence. Together, they define the values of the company and promote the essence of why the organization exists. A founder with a clear set of values regarding his or her employees is more likely encourage a consistent culture (Mathis and Jackson, 1988).

The starting point is designing the appropriate structures and to focus on the activities necessary to reach goals (of the company). Management analyzes the jobs that are to be performed (Boone and Kurtz, 1987).

The data collection for organization and management systems is based on the open sources such as information on the companies' web sites; printed materials and interviews with company employees including ex-workers. Some companies were resistant to providing detailed information and it has been respected were almost reluctant.

The Administrative Process Theory of Henri Fayol is based on economic efficiency and rationality. Although Fayol's theory does not cover only the organization issues but also other aspects of the management, the organization (structure) is the key element to investigate management aspects of a company (Kocel, 2007). So that is the reason why it is intended to conduct a study on these aspects of the shipping companies.

The Turkish shipping companies introduce generally a picture of family business type organizations. The management boards of these companies are generally composed of family members. Because of work and non-work lives are so intermingled, relations between individuals can affect business practices and decisions in the family type small business. Many who start small firms hope to build a business that can be turned over to a son or a daughter. Yet the younger generation may have different career aspirations and plans and do not ever want to work in the family business. When a business is passed on from one generation to another, there is a high probability that it will not be successful (Mathis and Jackson, 1988). 

Journal of Human Sciences, 12(2), 51-74. doi: 10.14687/ijhs.v12i2.3165

The span of the management (or span of the control) is the optimal number of the subordinates a manager can effectively supervise. Although the optimal number varies from one firm to the next, many management writers agree that top management should directly supervise no more than four to eight people. The critical factors in determining the optimal span of the management are the type of work performed, the workers' training, and the amount of the paper work involve, the manager's ability and the effectiveness of the communication (Boone and Kurtz, 1987). When we investigate the organization charts of the companies it is understood that the number of the subordinates under the general managers varies between twelve and twenty and it is more over the span of control.

The shipping companies may also be assumed as a logistic company as a nature of the work. The logistic companies have different entities from a regular organization and cover two groups of departments: Logistic Departments (Export-Import, Fleet Management, Operations, Air- SeaRoad-Rail Transportation, Customs, and Insurance etc.) and General Management departments (Marketing, H/R, Accounting, Administration, IT, Purchase, Quality Management etc.) (Erdal and Saygili, 2007). But only a few companies have been organized in this manner and not eligible to assume a logistic company responsibility. This is a factor which may hamper their improvement for future roles.

This is not to suggest that the shipping market sets out to release inaccurate or misleading information - although there have been occasional accusations, relating to settlements of forward (paper) contracts against reported market levels in the settlement period, of reports of 'rogue fixtures'. However, given that information circulates via a broker/media 'grape vine' - involving more players than those who might have actually been involved directly in the business - which introduces a degree of imprecision, is it going to be a surprise if 'owners' brokers' reports tend to round up the rate by the odd 50c or so? The truth, therefore, is that most players are 'second guessing' and this helps fuel speculation on market moves - and, hence, the sentiment that is an intrinsic part of the freight markets (Drewry, 2006).

The Turkish companies have no organizations and capacity for "reading the market" and that stops them from making strategic plans. Their plans are mainly based on 'second guessing' and very limited for challenges in the maritime world. 
Demirel, E. (2015). A study on the organization and management systems of Turkish shipping companies. International Journal of Human Sciences, 12(2), 51-74. doi: $10.14687 /$ ijhs.v12i2.3165

Whoever has responsibility for commercial management, the success or otherwise of the venture will hinge on two key factors; (i) an ability to 'read the market' and (ii) an element of luck. The latter may sound disconcerting to those not closely involved with shipping markets but the truth is that shipping markets are some way from being transparent. Hence, interpretations have to be made based on incomplete or imperfect information. This creates a mix of speculation and sentiment to go with the underlying 'realities'. Sentiment is not something suited to 'mathematical models' (Drewry, 2006). As it has been mentioned before, they lack the ability of reading the market and that makes them play their games on luck in which success is not always possible.

The main elements of the managing ships are based on the commercial and technical management and administration (see Figure 1). When we investigated the company organizations a lot of missing elements are observed in particular commercial management.

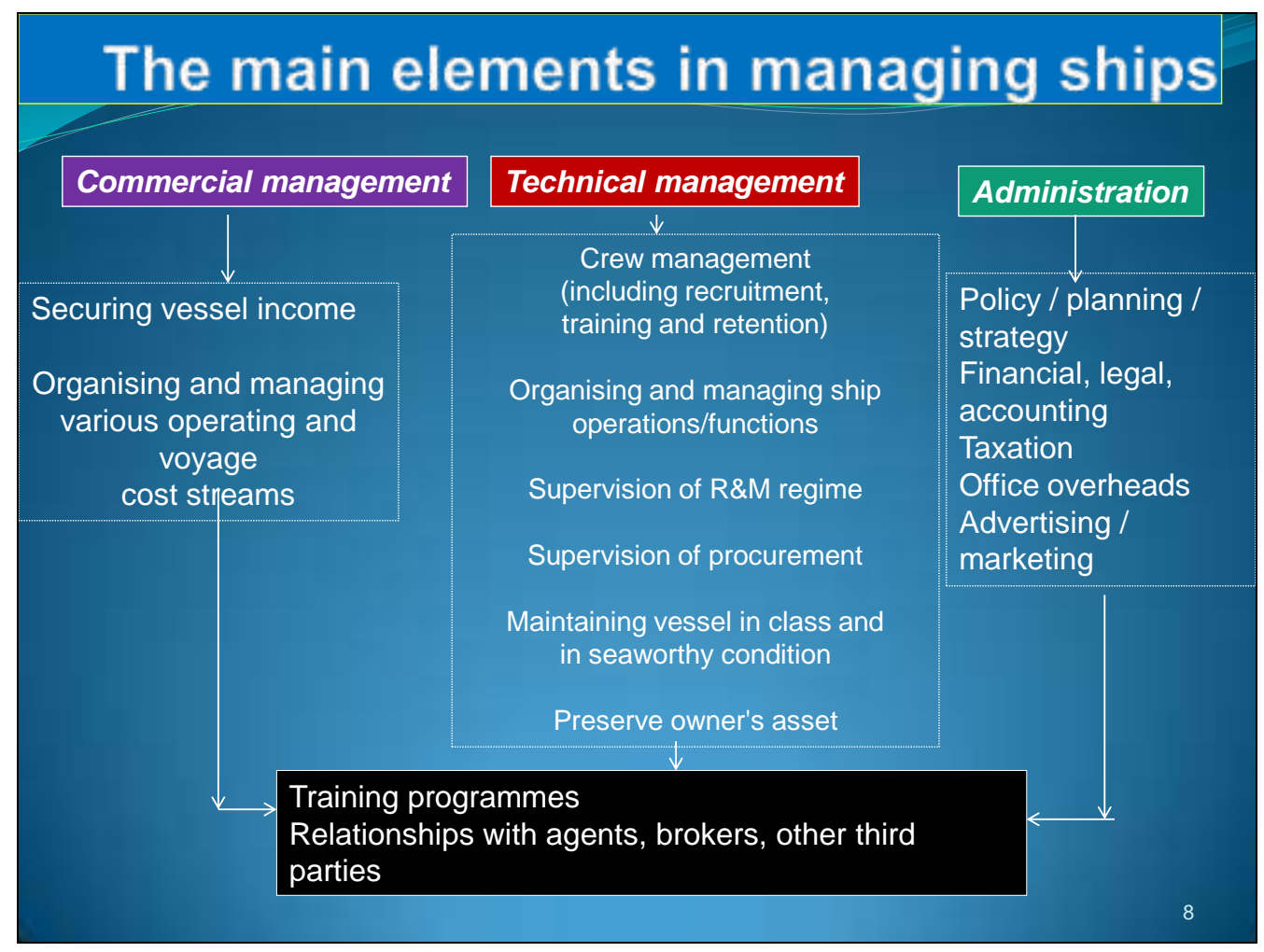

Figure 2: The main elements of ship management (Source: Drewry, 2006)

Most of the shipping companies in the country are involved in technical management and they do not have a commercial management capability. Within shipping, the effectiveness of an operation's commercial management will be determined by judgements made in the marketplace. These will relate to chartering choices, vessel acquisition and disposal strategies together with elements of cost 
control. Making the right choices and/or managing and containing the risks are difficult. This is because - although the shipping industry is regarded, more or less worldwide, as being one of the most open and genuine market places - the shipping market is far from being wholly transparent. Hence, there is a degree of skill needed to interpret the market information that is available (Drewry, 2006).

A new strategic management concepts has been introduced, namely Stakeholders Approach. The stakeholder concept can be useful in integrating some of these issues (plans and systems of the plans for business level entities, role of the corporation in the social systems, social responsibility of the business, behaviour of the large group of the populations of the organizations and their environments) around the concept of organization strategy, that is around the issues of how organizations can configure themselves and take actions to align themselves with the environment (Freeman, 2011). We are living in a rapidly changing world which needs to be adopted new system approaches. Unfortunately the companies have no intention to adopt new strategic concepts. This will create a negative impact on the success of these companies when they start to challenge in the competitive maritime market.

Any strategic management model must deal with a number of key questions. The questions listed below are some which can be understood partially in stakeholder terms:

- Strategic Direction (Direction or mission of organization)

- Strategic Programme Formulation (Paths of strategies)

- Budgeting(Resource allocation for application of the strategy)

- Control (To be sure that the strategies are on the track)

- Structure and System (Macro systems and structures for implementation)

Any information on the strategic management could not be reached in this study. It may be exist in the brain of the management board but not formulized or publicized. At least the existing or exemployees have no idea about such plans.

Liner and bulk shipping companies, which operate at opposite ends of the unit cost function, carry out fundamentally different tasks. Liner companies have to organize the transport of many small parcels and need a large shore-based staff capable of dealing with shippers, handling documentation and planning the ship loading and through transport operations. The bulk shipping industry, in 
Demirel, E. (2015). A study on the organization and management systems of Turkish shipping companies. International Journal of Human Sciences, 12(2), 51-74. doi: 10.14687/ijhs.v12i2.3165

contrast, handles fewer, but much larger cargoes. Large shore-based administrative staffs is not required, but the few decisions that have to be made are of crucial importance, so the owner or chief executive is generally intimately involved with the key decisions about buying, selling and chartering ships. In short, the type of organizations involved, the shipping policies, and even the type of people employed in the two parts of the business are quite different (Stopford, 2009). Some companies have taken necessary actions to conglomerate their different functions but some still have no intention to merge their liner and bulk shipping companies.

The new liner companies were highly visible organizations with offices or agencies in the ports they served. Companies such as P\&O, Blue Funnel, and Hamburg Süd became household names. Their prestigious office buildings housed teams of administrators, naval architects and operations staff who planned and directed fleets of a hundred ships or more as they plied back and forth on their trades (Stopford, 2009). The companies are reluctant to cooperate even for establishing common offices or agencies in the same areas.

As we progress through the early years of the twenty-first century, the size and scope of the shipping company will continue to change. It is based on the company business plan formulated by the directors. The following factors are relevant (Archer, 2008):

(a) The company will have one of its core objectives marketing. This is generating a new breed of management and culture throughout the company. It will remain customer focused, embracing responding and empathizing to the needs of the customer in a competitive manner. Hitherto, in previous generations it was driven primarily by operating considerations.

Moreover, the area of marketing embraces not only promotion strategies, but also market research, product development, including new types of containers, quicker transit and marketing plans including budget-driven marketing management.

(b) The IMO codes introduced in the past decade include the ISM, STCW, and ISPS codes which influence the company structure primarily in the marine sectors of the business. In particular, the chain of command between the ship and shore with emphasis on ship management and security.

(c) Logistics is a growth area in liner cargo companies.

(d) A further factor is the impact of information technology which continues to become more sophisticated and quickens the pace of the decision-making process. It extends 
Demirel, E. (2015). A study on the organization and management systems of Turkish shipping companies. International Journal of Human Sciences, 12(2), 51-74. doi: 10.14687/ijhs.v12i2.3165

all parts of the shipping company organization and in many companies has resulted in layers of management structure - especially in the middle management range - being eliminated. This has shortened the decision management chain and resulted in quicker decisions thereby making the company more competitive.

(e) At the same time the headquarters structure tends to be much smaller with authority devolved to encourage more accountability of personnel at all management levels. The profit centre concept has been developed through strong budgeting management techniques. The devolution of executive authority has involved cross border structures and in so doing yielded tax benefits and lower wage scales. The development of computerized technology has greatly facilitated this devolution and change.

(f) A further factor is the diversification of the business. Whilst shipping may remain the core of the business many entrepreneurs have other interests which include real estate and construction, including ancillary activities of the core business such as road haulage, seaports, warehouse, ship broking and so on.

(g) The development of third party ship management outsourcing is a growth section especially in the area of crew, insurance, ship survey and bunker management.

(h) The tendency to have more operating alliances.

(i) An increasing number of shipping companies are focusing on mergers and acquisitions.

Some Turkish shipping companies have made attempts to improve company management systems but these attempts do not cover all above mentioned subjects. A significant issue which has been actualized by all companies is the improvement of the IT systems.

This is to exploit the economies of scale and to raise capital to fund new tonnage and infrastructure, especially information technology. An example is the merger of P\&O Nedlloyd and Maersk Line, to form the Maersk Line. Today, there are fewer but mega container operators as they continue to merge. The outcome of these developments is the emergence of a new breed of shipping executive who must be thoroughly professional in the shipping business to which he or she is assigned, professionally qualified, market driven in attitude, very assiduous, culture orientated, multilingual, profit motivated and computer literate. Moreover, such personnel must be subject to continuous training to keep ahead of technology, market environment opportunity, and business techniques strategy (Archer, 2008). 
Demirel, E. (2015). A study on the organization and management systems of Turkish shipping companies. International Journal of Human Sciences, 12(2), 51-74. doi: $10.14687 /$ ijhs.v12i2.3165

The companies are generally led by merchant fleet origin staff, shipmasters and chief engineers, seafaring officers. But most of the staff has no formal experiment on maritime management which is vital. And there is still a language problem of the staff which communication in English is an inevitable requirement in the maritime business.

The size of the shipping undertaking, its organization and cost structure, and the pricing of sea transport services are influenced largely by the type of service which is operated, and particularly by the difference between liner and tramp operation. Hence there is a great variation in size among shipping undertakings, which range from the single ship company, to the giant groups. From an economic standpoint, the entrepreneur will try to maximize his profits and therefore expand his output, so long as the increase in his total costs is less than the increase in his total revenue. He will therefore continue to expand to the point where his marginal additional cost is equal to his marginal additional revenue. The tendency in recent years, both with liner and tramp shipping companies, is to merge. The reasons are numerous and include economies realized on administration cost; improved prospects of raising more capital for new tonnage; rationalization of facilities, for example port agents, departments, overseas offices, berths, ports of call, etc.; the long-term consideration of likely improvement on tonnage utilization and productivity, with possible limited rationalization of a fleet and centralization of marine department activities covering manning, management, survey programme and new building; a larger customer portfolio; a larger trading company with improved competitive ability and the long-term possibility of a more economical service at lower cost with consequently improved tariffs; and finally the larger the company, generally speaking, the better it will be able to combat the challenges of the twenty-first century in particular with regard to new investment, which will be vast, and competition, which will intensify (Archer, 2008).

It is not possible to say that Turkish companies are ready to apply or have intention to achieve the above mentioned roles. Even there is no intention to establish consortiums to achieve some specific economic goals may be beneficial for all interested parties.

Ship management companies fall into main categories, one being a ship-owning company that manages its own ships and offers the same services to the other ship owners. The other types are companies that have no ships of their own and solely provide ship management services to the shipowners: Whichever type it is, the function is the same and falls under five main headings (ICS, 2006); 
- Crewing

- Technical

- Storage

- Insurance

- Operations

Turkish shipping companies are generally "industrial shipowners" companies and deals with technical management only. A few technical management companies have been established after 1995 and the number of such companies is increasing when the number of the "propriety ship owners" increases.

The Germanischer Lloyd and Fraunhofer CML (2014) conducted a large scale study involving 100 ship management companies across the globe to find what they are doing to improve their operation and what they consider as best practices in the industry. The companies have explained that their biggest challenges of ship management in mid-term future in five areas; Crewing (88\%), Technical Management (62\%), Financial Management (\%50), Quality and Safety (\%27) and procurement $(12 \%)$.

There are some shipping companies in Turkey showing a growing trend in the past ten years such as YASA, GEDEN and ARKAS. Such companies are following all improvements in the sector and trying to organize their headquarters very similar to famous shipping companies. So, all above mentioned challenging management issues should be considered also for them.

\subsection{The Findings of the Research}

It could be possible to reach the management related information of the 17 shipping companies. The important findings are resumed in the following tables. The detail will be discussed in the following paragraphs.

Table 1: Existence of the Management Branch/Departments of the 17 companies

\begin{tabular}{|l|c|c|}
\hline Commercial Department & YES & NO \\
\hline Existence of Commercial Department & 5 & 4 \\
Cahartering Capability & 9 & 8 \\
FFA Capabity & 2 & 15 \\
Outsourced & 8 & 9 \\
\hline
\end{tabular}


Demirel, E. (2015). A study on the organization and management systems of Turkish shipping companies. International Journal of Human Sciences, 12(2), 51-74. doi: 10.14687/ijhs.v12i2.3165

\begin{tabular}{|l|c|c|} 
Technical Management & YES & NO \\
\hline Existence of Technical Managent Department & 15 & 2 \\
Operations Branch & 16 & 1 \\
R/M Branch & 14 & 3 \\
New Ship Building & 3 & 14 \\
Crewing & 15 & 2 \\
\hline Administration & YES & NO \\
\hline Legal Branch & 2 & 15 \\
Finance Branch & 2 & 15 \\
Budgetting Branch & 3 & 14 \\
Accounting & 17 & 0 \\
Public Relations & 3 & 12 \\
\hline
\end{tabular}

Table 2: Major Claims Related to the Management by Key Staff

\begin{tabular}{|l|c|}
\hline Claim & Number of the Companies \\
\hline Existence of no startegic Plan & 13 \\
\hline Day by Day operation & 16 \\
\hline Lack of cooperation with foreign companies & 9 \\
\hline Nocompany culture & 11 \\
\hline
\end{tabular}

Table 3: The Composition of the Upper and Middle Management

\begin{tabular}{|l|c|c|}
\hline Composition of Upper Management & Fully Family Members & $\begin{array}{l}\text { Plus } \\
\text { Managers }\end{array}$ \\
\hline Board of the Managers & 13 & 4 \\
General Managers/Managing Directors & YES & NO \\
\hline Existance of Deputy Managers & 4 & 13 \\
\hline DPA assuming Deputy Manager Role & 9 & 4 \\
\hline Composition of the Middle Management & Number of the companies \\
\hline Fully Ship Master/Chief Engineer & \multicolumn{2}{|c|}{5} \\
\hline Mostly Ship Master/Chief Engineer & \multicolumn{2}{|c|}{4} \\
\hline Seafarers origin rather than others & \multicolumn{2}{|c|}{2} \\
\hline Other professionals rather than Seafarers origin & \multicolumn{2}{|c|}{2} \\
\hline No saefarer origin & & \\
\hline
\end{tabular}


Demirel, E. (2015). A study on the organization and management systems of Turkish shipping companies. International Journal of Human Sciences, 12(2), 51-74. doi: 10.14687/ijhs.v12i2.3165

Table 4: Deployment of the Headquarter Staff

\begin{tabular}{|l|c|}
\hline \multicolumn{2}{|l|}{ Number of the personnel deployed at the HQ } \\
\hline Number of the employee & Number of the companies \\
\hline 3 t0 5 & 2 \\
\hline 6 to 10 & 2 \\
\hline 11 to 15 & 3 \\
\hline 15 to 20 & 4 \\
\hline 20 to 30 & 2 \\
\hline 31 -more & \\
\hline Twin Mandate & 2 \\
\hline Number of the employee & Number of the companies \\
\hline 6 to 8 & 4 \\
\hline 5 to 7 & 3 \\
\hline 3 to 4 & 6 \\
\hline 1 to 2 & \\
\hline
\end{tabular}

\subsection{Overall assessment to be introduced to SWOT team}

The information concerning to the Turkish companies is evaluated in light of the general organization and management principals mentioned above as well as the specific issues concerning maritime economics and management.

The significant findings related to the Turkish shipping companies are as follows:

- There is not a commonality in the organization charts. But some essential departments are such as Operations, Technical Management and Crew Management are exist in the all companies with same name

- The companies are involving technical management and generally has no department responsible for commercial management

- As a result of the lack of commercial management, almost every companies have three major departments (Operations, technical Management and Crew Management)

- The companies introduce a family type business. So there is not professional managers at Upper Management (Board of the Managers)

- The general managers are generally family members and plays Managing Director (is also member of the management board) role 

Journal of Human Sciences, 12(2), 51-74. doi: 10.14687/ijhs.v12i2.3165

- To avoid the heat of the execution process, the most of companies are structured as "one ship-one company" basis. But all ships assigned different companies are directed from the same headquarter

- Informal organization is rather dominant in the management system

- Some of the positions on the organization chart are not manned

- Some of the positions are twin mandate (some separate positions are manned with same personnel)

- DPA (Designated Person at Shore) post is likely play a Deputy General Manager role in some companies with TQM or Health and Safety System (OHSAS) Manager functions

- There is not an assigned person for Finance and Budgeting and Accounting Department play their roles

- Although some companies has a legal adviser in their organization chart there is no person assigned and generally outsourced

- The office personnel in the key positions are merchant fleet origin. Others are not formally qualified in the maritime management but become eligible for job after long duration work at the company

- Every company has a strategic plan in the mind of the upper management but no formal strategic plan is not detected

- The shipping companies are not in the stock market except one (actually it is accidental)

- Some major companies has a Ship Construction and S/P (Sales and Purchase) unit

- Commercial management is outsourced or a few companies uses their commercial corporation of their conglomerate

- There is no entrenched company culture and as a result sense of loyalty is unlikely does not exist

- Day by day operation is commonly applied and there is not long term even mid-term plans

- Not sufficient company information (telephone directory, organization charts, point of contacts et.) on the web sites

- Too many departments (up to 20) directly reporting to general managers. No deputy managers are established to supervise/direct some departments which may be grouped under same functional groups

- No company has a department responsible for foreign relations and there is no foreign staff in the organization 

Journal of Human Sciences, 12(2), 51-74. doi: $10.14687 /$ ijhs.v12i2.3165

\section{SWOT analysis}

SWOT is an acronym for business analysis technique devised at the Stanford University during the 1970s by a team led by Dr Albert Humphrey. Performing a SWOT analysis allows us to analyse the big issues, and will help the organization upon your thoughts about your business's present situation. Business issues will doubtless be visible in all business areas (Lloyd, 2012):

- Market(s) and individual customer groups

- Competitors

- People

- Finances

- Technical aspects of your products or service

- Securing the supply of essential raw material and specialized labor

- Business process

A SWOT analysis team, which consists of five people from a maritime background and whose expertise is in maritime management, was established. A five-day study was conducted.

The grouped information and some related information have been associated. The collection has been introduced to group members. A sample study has been discussed by group members to be familiarized with SWOT procedures.

The SWOT (Strengths and Weakness \& Opportunities and Threats) study has been started by evaluating organization charts which is highly important to evaluate the Strengths and Weakness. The advantages and disadvantages of the existing organizations are compared taking into account of the four forms (Line, Line and Staff, Committees, Matrix) of Organization (Boone and Kurtz, 1987).

The group discussions continued for two days to define four main elements of the analysis. An Ad Hoc group has studied on PRIMO and PESTEL tests to eliminate some findings which are not acceptable or applicable. The final draft has been introduced to the group members and having their inputs the study has been finalized.

\subsection{Weaknesses}

- The companies has no department responsible for commercial management and that limits their commercial management capability $(2 / 2)^{2}$ 

Journal of Human Sciences, 12(2), 51-74. doi: 10.14687/ijhs.v12i2.3165

- Still "one ship - one company" organization is applied that create negative impact on reputation $(1 / 1)$

- The companies have no strategic plan even mid-term plans, so decision can be too spontaneous $(1 / 2)$

- Informal organization is dominant rather than formal (3/3)

- Day-to-day fire fighting rather than strategy $(1 / 1)$

- Absence of professional managers at the upper management (direction) $(1 / 1)$

- No finance and budgeting department $(2 / 2)$

- Some posts are not manned or twin mandate (3/3)

- Middle management level are merchant fleet origin and qualified (2/2)

- Legal issues are outsourced and no assigned legal experts (3/4)

- Some general managers are family members without market experience (2/3)

- Middle and lower management level are not formally qualified on maritime management $(2 / 3)$

- No departments to conduct abroad cooperation (2/3)

- There is only one company in the stock exchange and this creates a negative impact on ship finance $(3 / 3)$

\subsection{Strengths}

- Information systems grows and facilitates management activities (1/1)

- The shipping companies have sufficient experiment to reorganize as a logistic company $(2 / 3)$

- Organization has an experiment to handle a regular supply chain management system (2/3)

- Some companies work different type of commodity transportation $(2 / 2)$

- Close family relations between many ship/company owners facilitates cooperation and mutual support (3/3)

- The young people still admires to become seafaring officer and it facilitates employment of sufficient number of crew $(2 / 2)$

- There is a well organized and capable organization namely IMEAK DTO to provide cooperation and coordination in the sector $(2 / 3)$

- Good cooperation between private sector organizations and Maritime Administration (2/3)

- Product knowledge of the staff is sufficient (3/3)

- $\quad$ Staff team enthusiasm is still considerable $(2 / 3)$ 
Demirel, E. (2015). A study on the organization and management systems of Turkish shipping companies. International Journal of Human Sciences, 12(2), 51-74. doi: 10.14687/ijhs.v12i2.3165

- Ideas generation exists but needs to be organized and supported (1/3)

- The companies are well aware of the facts of the new maritime order but needs more proactive approach $(1 / 1)$

\subsection{Assessment of Threats and Opportunities}

The threats and opportunities are defined taking into account the impacts of the weaknesses and strengths of each management functions on the business functions of the companies. The Figure 3 is used as a reference for this purpose. The commercial and technical functions are assumed vital for the company to survive and continue to operate. The unavoidable and potentially optional business functions are discussed.

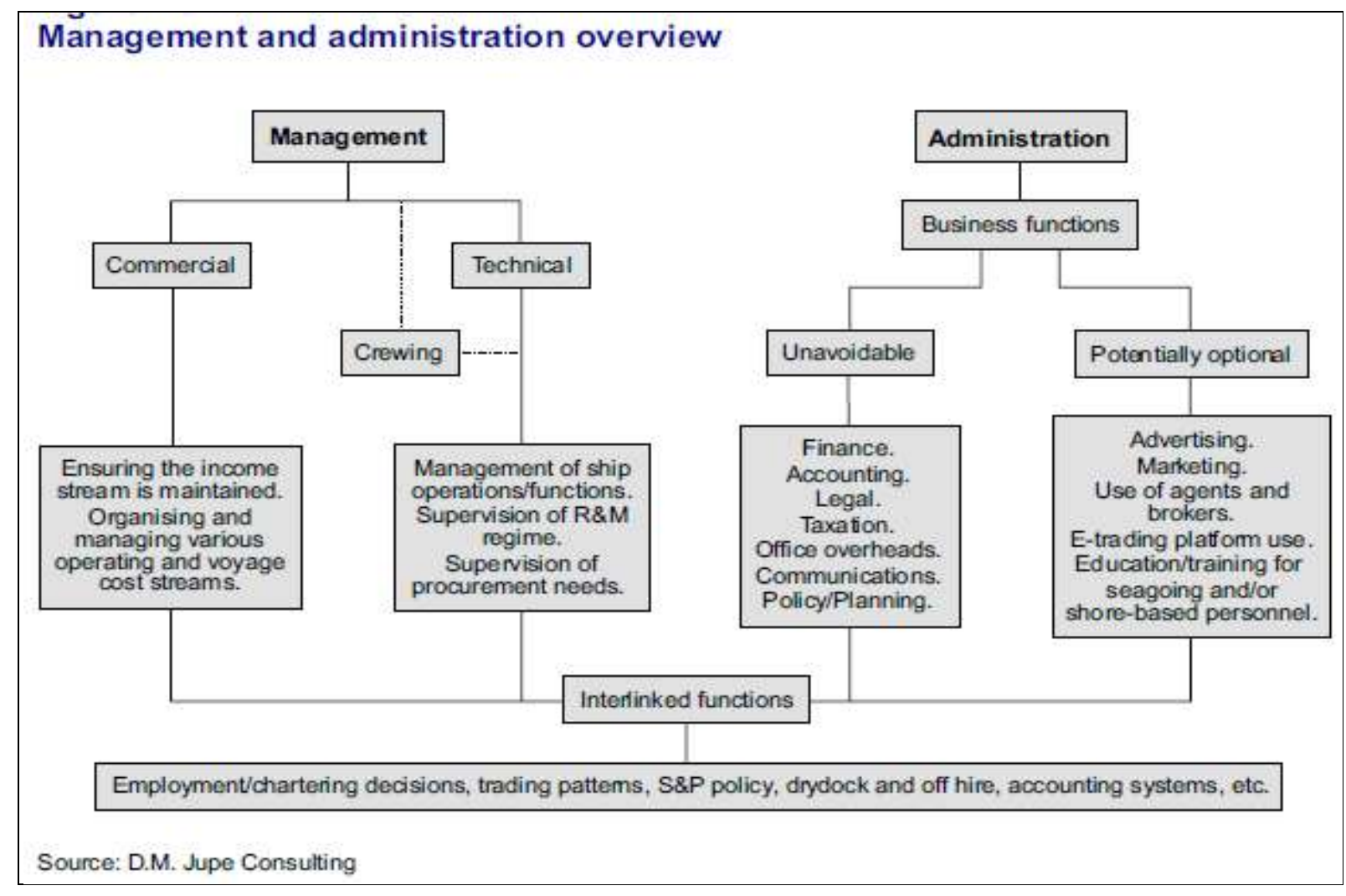

Figure 3: The impacts of the each management factors on business functions (Source: Drewry, 2006)

\subsection{Threats}

- Economic cycle is still unpredictable. The organization is not suitable to create any strategic plan and handle a risk management plan which is vital to the survival of the company.

- The commercial management capability is very low. The freight rate is still low and if they do not enhance customer range, they may not be able to continue to compete. 
- The composition of the world fleet is rapidly changing and modern ships are replacing old ships. They have no specific department to handle ship supply and purchase activities for fleet renewal.

- The number of the shipping companies is increasing and many copycats in the future are possible. The organization and management system is not sufficient to fully support the company in a maritime sector with too many competitors.

- No departments exist for finance and budgeting functions. Inadequate focus on the finance/cash-flow

- Key staff is changing often. This situation may create many gaps in the management system and hampers long term planning.

- Family members influence on the decision process may hamper regularity of the company management systems.

\subsection{Opportunities}

- Many road transportation companies in the country are transformed into logistic companies. The shipping companies have sufficient experiment and reorganization capability to assume logistic company roles as a complementary business and reorganize to achieve such functions.

- Many companies have adopted management information systems which facilitate their management activities. This gives them an opportunity to create a data mining capability which improves their customer relations and acquisitions and purchase abilities.

- An effective supply chain management system may be developed with some minor changes in the organization.

- Some companies work different type of commodity transportation (bulk, tanker, container etc.) This will help them to survive in case of any negative impact on freight rate for a specific type of commodity.

- Close family relations between some ship/company owners may facilitate cooperation and mutual support. This situation also helps them to create strong NGOs in the sector.

- The sector still has a capability to employ sufficient number of crew/personnel but needs some effort to improve quality.

- Potential investors are hovering but needs to be organized for cooperation

- IMEAK Chamber of Shipping is a well organized and strong institution and capable for athletic sponsorship for the sector 


\section{Conclusion}

As a result of this study it is understood that the Turkish shipping companies have mostly not adopted contemporary business and management practices. The success of a company is dependent upon correct decisions to provide smooth operation of the organization and also the "luck" factor. It is evident that all institutions should adopt new business management techniques and practices to survive in a challenging economic system.

The followings are suggested for the companies to improve their business organization and management system:

a. Too many departments (up to 20) directly reporting to the general manager and it is out of the control range. There is no deputy for the general managers. Some departments should be grouped and reorganized under a Deputy General Manager to provide better control and coordination.

b. Twin mandate is not an effective way of deployment. If possible the unification of some departments is considered as more feasible to solve this problem.

c. Professional managers are required for both upper and middle level management positions rather than employing family members in these posts. These will provide feasible, productive and reliable operation of the company. Instead of a general manager, a managing director (also a board member) position will be more suitable to be able to respond in emergency situations.

d. The ship Sales and Purchase $(\mathrm{S} / \mathrm{P})$ is an essential function of the company to apply a strategic plan for surviving in volatile maritime business. A new department named S/P in coordination with Finance Department is required. The companies in growing trend needs to establish such a department soon.

e. Finance, Budgeting and Accounting are related but totally separate functions. These departments should be definitely separated but may be compiled under a deputy general manager.

f. Operating as a family type small business may be acceptable at beginning (the period of founders operates the system) but gradually a contemporary professional management systems practice requires when the second generation take over the direction.

g. The company culture is an essential element to secure the systems against misleading and to be able to survive the company in case of crisis upraise.

h. In the light of the Stakeholder Management concept and practice, the professional managers with experience and good contacts with stakeholders (government, NGOs, media, other companies in the sector, related chambers etc.) are key elements to solve the problems which may hamper the company activities. 
Demirel, E. (2015). A study on the organization and management systems of Turkish shipping companies. International Journal of Human Sciences, 12(2), 51-74. doi: 10.14687/ijhs.v12i2.3165

i. The nature of the maritime business is a volatile and generally not a transparent. To survive in such an uncertain environment a shipping company needs a "Strategic Plan" which covers a foreseen future.

j. The reorganization of shipping companies as logistic companies may empower them and helps them to survive in crises period at the shipping sector.

$\mathrm{k}$. The maritime business has an international feature and shipping companies strongly need to establish a link with global counterparties.

1. Not having a financial management capacity hampers ship finance opportunities and subsequently hardens implementation of a strategic plan for improvement.

Finally,

Ship management is not easy. Partly this is due to the physical nature of shipping. Also, shipping operates within a complex and ever changing market set up. Fundamental to the success of the entire shipping equation is the quality of the management operation behind the ships that service global trading needs (Drewry, 2006). To survive in a challenging business, the organization and management are vital elements for shipping companies. With a fleet of over 30 million DWT, the Turkish shipowners are to reorganize their organization and management systems in line with the contemporary governance concepts and if required they need professional assistance in this regard.

\section{References}

Archer A. B., (2008). Elements of Shipping, $8^{\text {th }}$ Edition, Routledge, New York, ISBN 978-0-415-36286 0 p. $279-181$

Avcioglu D., (1969). Turkey's Layout (Turkiye'nin Dureni), Volume 5, Bilgi Yayinlari, Istanbul p. 194, $220,364,368,369$

Boone L.E. and Kurtz D.L., (2008). Contemporary Business, Dryden Press, New York ISBN 0-03006199-7 p. 174, 176, 177, 186, 187

Camci, B., Zafer C., Yaman S., (1994). Maritime Corporation, The History of the Turkish Shipping and Maritime Corporations (Turk Deniz. Ticareti ve Denizcilik Isletmeleri Taribi), Volume I and II, Hermes Sahaf, Istanbul

COGITO, (2006). Special Issue- Ottomans (Osmanlilar Özel Sayisi), Yap1 Kredi Kültür Sanat Yayınlari, Istanbul, ISBN 1300-2880 p. 19, 188, 191

Drewry, (2006). Ship Management, Drewry Shipping Consultants Ltd., London p. 1, 11, 54

Erdal M. and Saygili M., (2007). Management- Organization and Fleet Management at the Logistic Companies (Lojistik Isletmelerinde Yonetim-Organizasyon ve Filo Yonetimi), Zebra Matbaaclik ve Baski Hizmetleri A.S., Istanbul ISBN 978-975-92469-6-9 p.12, 13

Freeman R.E., (2011). Strategic Management, Cambridge Press, Noida ISBN -13 978-107-16851-0 p. 43, 45

Fraunhofer CML and GL, (2014). Best Practice Ship Management Study 2013, GL Maritime Software Product, Hamburg OE845-2013-04-01 p. 2, 6

ICS (Institute of Chartered Shipbrokers), (2006). Introduction to Shipping, Whitherby Co Ltd., London p. 65 
Demirel, E. (2015). A study on the organization and management systems of Turkish shipping companies. International Journal of Human Sciences, 12(2), 51-74. doi: 10.14687/ijhs.v12i2.3165

IMEAK Chamber of Shipping, (2013). Maritime Sector Report 2012, Istanbul ISBN 978-9944-60-7063 p. 19,20

Kocel T., (2007). Business Management (Isletme Yoneticiligi), Arian Basim Yayin Ltd, Istanbul ISBN $975-$ 6145-44-7 p. 153

Lloyd D., (2012). Business Plans, Hodder Education, London ISBN-13:978 0340946503 p. 26,181

Mathis R.L. and Jackson J.H., (1988). Personnel/Human Resources Management, West Publishing Company, St. Paul ISBN 0-314-62317-5 p. 37, 571, 577

Ortayli I., (2006). The Longest Century of the Empire (Imparatorlugun En Uzun Yusyili), Alkim Yayinlari, Istanbul, ISBN 975-992-008-5 p. 18

Sirin V., (2000). Outline of Political and Cultural History of the Ottoman (Anabatlaryla Siyasi ve Kulturel Osmanli Tarihi) Marifet Yayinlari Istanbul, ISBN 975-359-089-X p. 92

Stock J. R. and Lambert D. M., (1993). Strategic Logistics Management, Irwin ISSN: 0256088381

Stopford M., (2009). Maritime Economics, $3^{\text {rd }}$ Edition, Routledge, New York ISBN 0-203-89174-0 p. $31,32,77$

Tallack R., (2007). The Commercial Management, Nautical Institute, Middlesex ISBN 1870077334

Turkish Government, (1928). Law No: 618, Law of the Ports (Limanlar Kanunu), Statutory Gazette dated 21 April 1341(1928): No: 95, Ankara

Turkish Government, (1982). Law No: 2581, Improvement of the Merchant Fleet and Incitement of Shipbuilding Industry, Statutory Gazette dated 21 January 1982 No: 17581, Ankara 